AperTO - Archivio Istituzionale Open Access dell'Università di Torino

\title{
Horticultural and floricultural applications of urban wastes originated fertilizers
}

\section{This is the author's manuscript}

Original Citation:

Availability:

This version is available http://hdl.handle.net/2318/122778

since

Terms of use:

Open Access

Anyone can freely access the full text of works made available as "Open Access". Works made available under a Creative Commons license can be used according to the terms and conditions of said license. Use of all other works requires consent of the right holder (author or publisher) if not exempted from copyright protection by the applicable law. 


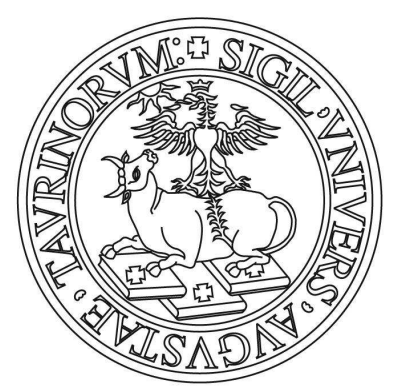

\section{UNIVERSITÀ DEGLI STUDI DI TORINO}

This is an author version of the contribution published on:

Questa è la versione dell'autore dell'opera:

Compost Science Utilization, 20,3, 2012,http://dx.doi.org/10.1080/1065657x.2012.10737040

The definitive version is available at:

La versione definitiva è disponibile alla URL:

www.tanfonline.com 
Horticultural and floricultural applications of urban wastes originated fertilizers

M. NEGRE ${ }^{1}$, C. MOZZETTI MONTERUMICI ${ }^{1}$, D. VINDROLA ${ }^{1}$, G. PICCONE ${ }^{1}$, D.G. PERRONE ${ }^{2}$, L. TOMASSO $^{2}$, E. MONTONERI ${ }^{2}$

1. Dipartimento di Valorizzazione e Protezione delle Risorse Agroforestali, Università degli Studi di Torino, via L. da Vinci 44,10095 Torino, Italy

2. Dipartimento di Chimica Generale e Chimica Organica, Università degli Studi di Torino, Via P. Giuria 7, 10125 Torino, Italy

Corresponding author: Michèle Negre: michele.negre@unito.it 


\begin{abstract}
Different origin composts and a digestate from a biogas plant and their respective alkali soluble (SBO) and insoluble (IOR) fractions have been tested as organic fertilizers in growth media. The materials have been characterized by determination of $\mathrm{pH}$, salinity, $\mathrm{C}, \mathrm{N}, \mathrm{P}$, and $\mathrm{K}$ content. A preliminary evaluation of the possible phytoxicity has been performed by determination of the germination indexes of cress (Lepidium sativum), white mustard (Sinapsis alba) and radish (Raphanus sativus). Most of the materials did not promote the germination of the seeds. Notwithstanding these negative results, the materials were also used as partial peat substitute in a commercial substrate to test the growth of marigold (Tagetes patula), radish (Raphanus sativus), and spinach (Spinacia oleracea). The dimension and dry weight of the plants grown on the substrate mixed with the composts, the digestate or the SBOs were similar to those observed on the substrate. Moreover, most of the SOBs provoked the increase of the dry weight of the roots of the radishes, therefore an increase of the quality. The insoluble fractions (IOR) from the composts allowed a growth of the plants similar to that obtained with a commercial substrate. In contrast, the IOR obtained from the digestate was phytotoxic.
\end{abstract}




\section{Introduction}

Although soilless horticulture and floriculture rely largely on peat sourced from bogs, many studies have demonstrated that peat can be substituted by alternatives such as compost, sewage sludges and other transformed wastes in growth media preparations (Ingelmo et al., 1998; Raviv et al., 1998; Ozores-Hampton et al., 1999; Bustamante et al., 2008; Herrera et al., 2009; Andersen et al., 2010; Boldrin et al., 2010; Jayasinghe et al., 2010).

Compost is one of the most adapted materials to substitute peat in nursery for both its physical and chemical properties, as for example its high content of humic-like compounds which have been largely investigated (Prudent et al., 1995, Lguirati et al., 2005, Campitelli et al., 2006, Francioso et al., 2007). Another promising organic fertilizer is the digestate coming from the anaerobic biological digestion process by which, in the absence of oxygen, organic matter is transformed into biogas. Because of the high nutrient content $(\mathrm{N}, \mathrm{P}, \mathrm{K})$ in available form, the digestate slurry appears to be a very good candidate to replace inorganic fertilizers (Tambone et al., 2010).

Recently, it has been demonstrated that alkali soluble organic material (SBO) extracted from urban wastes originated composts have promising performances as chemical auxiliaries for a number of technological applications in the chemical industry and in environmental remediation i.e., textile dyeing (Savarino et al., 2009), detergents manufacture (Savarino et al., 2010), hydrocarbons contaminated soil washing (Montoneri et al., 2009), light-induced oxidation processes for environmental remediation of waste waters (Bianco Prevot et al., 2011), and templates for the synthesis of porous materials with tailored morphology (Boffa et al., 2010). Promising results have been given by SBO in promoting the green house growth of tomatoes (Sortino et al., 2011). The insoluble residue (IOR) left after extraction of SBO is a by-product which possible uses have not been investigated.

The scope of this paper was to check the capacity of different urban wastes originated organic materials (starting materials) and the respective SBO and IOR to partially replace peat in growth media for some typical 
horticultural and floricultural species. The starting materials were different origin composts and a digestate from a biogas production plant.

\section{Materials and Methods}

\section{Urban wastes}

The starting materials were a digestate slurry obtained from source separated organic wastes in a biogas plant production (SSOD), a compost from green wastes (CG), a mixed compost from green wastes and SSOD (CGD), a mixed compost from green wastes and sludges from a waste water treatment plant (CGS), a mixed compost from green wastes, sludges from a waste water treatment plant and SSOD (CGSD). All materials were supplied by Acea Pinerolese Industriale SpA, Pinerolo (TO), Italy.

Preparation of the soluble (SBO) and insoluble fractions (IOR)

The preparation of the soluble fraction was performed in a pilot plant by treatment of the starting materials with a $0.1 \mathrm{M} \mathrm{KOH}$ solution (1L solution/ $\mathrm{Kg}$ solid) under stirring at $60{ }^{\circ} \mathrm{C}$ for $4 \mathrm{~h}$. The reaction mix was allowed settling to separate the supernatant liquid containing the soluble fraction (SBO) from the solid residue (IOR). The liquid phase (SBO) was centrifuged to separate fine solid particles. The IOR residue was washed once with water at $4 \mathrm{~L} \mathrm{Kg}^{-1}$ liquid/solid ratio. The recovered SBO solution and IOR solid products were allowed to concentrate and/or dry in ventilated oven at $60{ }^{\circ} \mathrm{C}$ until reaching a residual moisture under 20 $\%$.

\section{Characterization of the materials}

$\mathrm{pH}$ and electrical conductivity were measured on freshly collected samples in 1:5 (w/v) aqueous extract. C and $\mathrm{N}$ content were measured by elemental analysis of $0.5 \mathrm{~mm}$ sieved samples. The total $\mathrm{P}$ content was determined colorimetrically (phosphomolybdic complex), after nitric-perchloric acid digestion. The potassium content was determined by atomic absorption after nitric acid digestion.

\section{Composition of the growth media}

The tested materials were added to a commercial substrate (Evergreen ammendante torboso, provided by Turco Sulvestro snc, Turin, Italy) with the following characteristics: peat $>50 \%, \mathrm{pH} 6.5$, organic $\mathrm{C} 30 \%$, 
organic N $0.8 \%$. The growth media were prepared by mixing the materials with the substrate on a $30 \%$ (V/V) basis. The corresponding concentrations expressed as dry matter were about $70 \%(\mathrm{~W} / \mathrm{W})$ sludge and composts, $25 \%$ (W/W) SBO and $60 \%$ (W/W) IOR.

\section{Germination bioassay}

Seeds of cress (Lepidium sativum), white mustard (Sinapsis alba) and radish (Raphanus sativus) were germinated on filter paper moistened with deionised water for control treatment or with aqueous solutions prepared by water extraction of the materials $(85 \% \mathrm{w} / \mathrm{w})$ diluted to 50 and $75 \%(\mathrm{w} / \mathrm{w})$ for sample treatment. The percentage of germinated seeds and the length of the roots were determined after 24 hours. The germination index (GI) was calculated according to the following equation:

$\mathrm{GI}=100 *$ (number of germinated seeds $\mathrm{x}$ mean radicle length - sample) $/($ number of germinated seeds $\mathrm{x}$ mean radicle length - control). The final result was the average of the values of the two concentrations.

\section{Plant growth experiments}

Experiments were carried out in the experimental farm of the Department at Carmagnola (Piemonte, North Italy). The first experiment was conducted under hail screen, from June to July 2010 on Tagetes patula (marigold) and Raphanus sativus (radish). Commercial marigold plants from nursery (17 cm height) were transplanted into the different growth substrates in $14 \times 14 \times 15 \mathrm{~cm}$ pots; radish was sowed into nursery trays and potted at three leaves stage in $9 \times 9 \times 10 \mathrm{~cm}$ pots, two plants for pot.

The second experiment was carried out into a greenhouse, from November to December 2010 on Raphanus sativus and Spinacia oleracea (spinach). Both species were sowed into nursery trays and transplanted at three leaves stage into $9 \times 9 \times 10 \mathrm{~cm}$ pots.

Control plants were grown on the commercial substrate. Five replications were established for each trial. The growth of plants was evaluated according to the following parameters: biomass production (dry weight) was determined for all the species; in marigold flower number/plant, foliage diameter, plant height were recorded. The growth of radishes was expressed as diameter and dry weight of the roots.

Statistical analysis 
The data were evaluated by one-way ANOVA $(\mathrm{P}<0.05)$ followed by the Tuckey test for Multiple Comparison Procedures.

\section{Results and Discussion}

\section{Characterization of the materials}

Some of the characteristics of the compost and sludge and the derived materials are reported in tables 1 to 3.

According to the organic carbon $(>20 \%)$, and the $\mathrm{C} / \mathrm{N}$ ratio $(<35)$ the composts (Table 1$)$ should be within the requirements of the standard UNI 10780 (1998), to be allowed in cultural growth media (type B). On the other hand, the salinity of all composts but CGSD is slightly above the limit required by the standard ( 80 meq/100g). The digestate (SSOD), although exhibiting a high $\mathrm{C}$ and $\mathrm{N}$ content, should not be adapted for application in growth media because of its very high salinity.

During the separation process, most of the organic material was extracted as soluble fraction (Table 2) while the insoluble fraction (Table 3) was largely inorganic as indicated by the low $\mathrm{C}$ content. The extraction process provokes an increase of salinity of both the fractions.

\section{Germination index}

Determination of the germination index is one of the most commonly used compost maturity test. Different methodologies are reported in literature for this assay including assessing compost extracts, direct seeding in compost, planting in a potting media containing compost, and using a variety of plant species (Aslam et al., 2008). In this work we used the recommended method of the standard UNI 10780 (1998) based on the evaluation of the germination of seeds of L. sativum in contact with aqueous extracts of compost. The standard includes a classification of the composts related to germination index: values above $70 \%$ indicate that the compost is mature enough to be used in growth media (type B compost) while the limit for field application is $40 \%$ (type A compost).

The germination index of L. sativum (table 4) for the four composts and the digestate was below $40 \%$ therefore none of these materials fulfil the requirements of the standard. On the other hand, variable responses of different seeds in germination bioassays have been reported (Komolis and Tziouvaras, 2009; Marchiol et 
al., 1999) and L. sativum is known to be a sensitive species, therefore we also conducted the test on $S$. alba and $R$. sativus seeds. The germination indexes of these species were close to $40 \%$ in the case of the compost CGD, while no relevant improvement took place in the other cases.

Some of the soluble fractions gave germination indexes (table 5) higher than the corresponding starting materials. Values above $70 \%$ were obtained by CGD SBO on $S$. alba and $R$. sativus and above $40 \%$ by CGS SBO on L. Sativum.

Very low germination values were obtained for the insoluble fractions of all the tested materials (table 6) suggesting that they should not be used in agricultural applications.

The conclusion of the germination assay, conducted on three different plants, was that most of the tested materials should be phytotoxic. Phytotoxicity is usually due to the presence of compounds such as ammonia, salts, heavy metals and/or organic acids in the compost extract (Komilis and Tziouvaras, 2009). There is no simple explanation for the phytotoxicity of the tested materials, except for the digestate SSOD and the corresponding soluble and insoluble fractions exhibiting a very high salinity. On the other hand, CGD SBO exhibited a higher salinity but was less phytotoxic than the corresponding starting material confirming that high values of this parameter do not always contribute to the phytotoxicity.

\section{Plant growth experiments}

Although the germination bioassays provide important information, they do not give a fully comprehensive description of the toxicity of sewage sludges/composts. (Benito et al., 2005, Oleszczuk, 2008). This is the reason why we also tested the materials for their capacity to substitute part of the peat in plant growth experiments, notwithstanding the indications of phytotoxicity given by the germination index.

\section{Growth of T. patula (marigold)}

Growth of marigold, assessed in growth substrates mixed with some of the studied materials, is reported in table 7. The compost CGSD, the digestate SSOD and the soluble fraction of SSOD SBO have promoted the growth of the epigeous part of the plants at levels not significantly different than that of the control. This is in 
contrast with the information given by the germination assay (table 4 and 5) indicating that these materials were highly phytotoxic.

In contrast, the performance of the insoluble fraction CGSD IOI was minor in terms of number of flower and height of the plants. The insoluble fraction oSSOD IOR inhibited completely the growth of the plants.

Growth of $R$. sativus (radish)

The results obtained in the outdoor and greenhouse experiments are reported on Tables 8 and 9 respectively. The results are expressed as dry weight and diameter of the roots.

The composts CGSD, CGD and the digestate SSOD have given results not significantly different than those of the control. The roots of the radishes grown on the compost CG exhibited the same diameter but a dry weight twice that of the plants grown on the commercial substrate attesting for the better quality of the radishes. CGS promoted the growth of the roots in terms of both dimension and dry weight. Therefore, addition of the composts and digestate to the commercial substrate not only did not provoke any phytotoxicity symptom but, in some cases, improved the performance of the substrate in terms of dimension of the plants. These results are surprising since all the materials but CGD inhibited the radish seeds germination (table 4).

All the tested SBO (table 8 and 9) have given results similar to the control in terms of size of the roots but an effect on the weight of the roots was observed, depending on the materials: no effect for CGS SBO, decrease for SSOD SBO and remarkable increase (about twice) for CGD SBO and CG SBO. This last result is promising since it should affect positively the quality of the food. Also in these cases, the growth experiments did not reflect the information given by the germination index on $R$. sativus except for CG.

The insoluble residues (IOR) deriving from CGSD, CGS, CGD and CG promoted the growth of the roots at levels not significantly different than those of the control plants. The digestate derived solid residue (SSOD IOR) was toxic for $R$. sativus as observed for marigold.

\section{S. oleracea (spinach)}


All the tested materials and their soluble and insoluble fractions have promoted the growth of S.oleracea leading to dry weights higher than that of the control (table 10). Because of the large variability of the data, the weight of the plants was significantly higher than that of the control only in the trials conducted with CGS and CGD.

\section{Conclusions}

The trials conducted under hail screen in summer and under green house in autumn on three different plants demonstrate that the composts (green or mixed) and the digestate from a biogas production can be mixed with the peat-based classical growth medium without reducing the quality of the production. Moreover, some of these materials have promoted the growth of $R$. sativus and T. patula at levels higher than the control trials. Also some of the soluble fractions (SBO) of the starting materials have given promising results, especially by promoting the growth of $R$. sativus. The main effect was an increase of the dry weight of the roots, therefore an increase of the quality of the radishes.

As far as the insoluble residue was concerned, SSOD IOR was highly phytotoxic. In contrast, the insoluble fractions of CG, CGS, CGD, and CGSD allowed a growth of the plants similar to that of the commercial substrate indicating that these materials can substitute the peat in growth media. Since these materials are byproducts of the production of SBOs, their good performance suggests that they could be used in the production of growth media or as field fertilizers.

The good performances in pot experiments of nearly all the tested materials, of their soluble fractions, and in some cases of their insoluble fractions are in contrast with the information given by the germination test. This test indicated that the extracts contained water soluble toxic compounds at concentrations high enough to inhibit or reduce the number of germinated seeds and the dimension of the radicle. In pot experiments, these toxic compounds are likely leached away or bound to the solid phase, therefore they do not affect the development of the plants. 


\section{Acknowledgements}

This work was carried out at the start with Regione Piemonte Cipe 2006 funds within the Biochemenergy project. The authors are grateful to Acea Pinerolese Industriale in Pinerolo, TO (Italy) for supplying the starting materials and to Studio Chiono ed Associati in Rivarolo Canavese, TO (Italy) for making available the SBO production test facility.

\section{References}

Andersen, J.K, Christensen, T.H. and Scheutz, C. 2010. Substitution of peat, fertiliser and manure by compost in hobby gardening: User surveys and case studies. Waste Manage., 30: 2483-2489.

Aslam, D.N., Horwath, W. and VanderGheynst, J.S. 2008. Comparison of several maturity indicators for estimating phytotoxicity in compost-amended soil. Waste Manage.,28: 2070-2076.

Benito, M., Masaguer, A., Moliner, A., Arrigo, N., Palma, R.M., Effron, D. 2005. Evaluation of maturity and stability of pruning waste compost and their effect on carbon and nitrogen mineralization in soil. Soil Sci., 170, 360-370.

Bianco Prevot, A., Avetta, P., Fabbri, D., Laurenti, E., Marchis, T., Perrone, D.G., Montoneri, E. and Boffa, V. 2011. Waste-derived bioorganic substances for light-induced generation of reactive oxygenated species. Chem. Sus. Chem., 4: 85-90.

Boffa, V., Perrone, D.G., Montoneri, E., Magnacca, G., Bertinetti, L., Garlasco, L. and Mendichi, R. 2010. A waste-derived biosurfactant for the preparation of templated silica powders. Chem. Sus. Chem., 3: 445-452.

Boldrin, A., Hartling, K.R., Laugen, M., and Christensen, T.H. 2010. Environmental inventory modelling of the use of compost and peat in growth media preparation. Resour. Conserv. Recy., 54: 1250-1260.

Bustamante, M.A., Paredes, C., Moral, R., Agullo, E., Perez-Murcia, M.D. and Abad, M. 2008. Composts from distillery wastes as peat substitutes for transplant production. Resou. Conserv. Recy., 52: 792-799.

Campitelli, P.A., Velasco, M.I., and Ceppi, S.B.: Chemical and physicochemical characteristics of humic acids extracted from compost, soil and amended soil. Talanta, 69: 1234-1239.

Francioso, O., Ferrari, E., Saladini, M., Montecchio, D., Gioacchini, P. and Ciavatta, C., 2007. TG-DTA, DRIFT and NMR characterisation of humic-like fractions from olive wastes and amended soil. J. Hazard. Matter. 149: 408-417.

Herrera, F., Castillo, J.E, Lopez-Bellido, R.J., Bellido, L.L. 2009. Replacement of a peat-lite medium with municipal solid waste compost for growing melon (Cucumis melo L.) transplant seedings. Compost Sci. Util. 17, 31-39.

Ingelmo, F., Canet, R., Ibafiez, M.A., Pomares, F. and Garcia, J., 1998. Use of MSW compost, dried sewage sludge and other wastes as partial substitute for peat and soil. Biores. Technol., 63: 123-129. 
Jayasignghe, G.Y., Liyana Arachchi, I.D. and Tokashiki, Y. 2010. Evaluation of containerized substrates developed from cattle manure compost and synthetic aggregates for ornamental plant production as a peat alternative. Resour. Conserv. Recy. 54: 1412-1418.

Komilis, D. Tziouvaras, I. 2009. A statistical analysis to assess the maturity and stability of six composts. Waste Manage.,29: 1504-1513

Lguirati, A., Ait Baddi, G., El Mousadik, A., Gilard, V., Revel, J.C. and Hafidi, M. 2008. Analysis of humic acids from aerated and non-aerated urban landfill composts. Int. Biodeter. Biodegr., 56: 8-16.

Marchiol, L., Mondini, G., Leita, L., Zerbi, G.1999. Effects of municipal waste leachate on seed germination in soil-compost mixtures. Restoration Ecology, 7, 155-161.

Montoneri, E., Boffa, V., Savarino, P., Perrone, D.G., Musso, G., Mendichi, R., Chierotti, M.R., and Gobetto, R. 2009. Biosurfactants from urban green waste. Chem. Sus. Chem., 2: 239-247.

Oleszezuk, P. 2008. Phytotoxicity of municipal sewage sludge composts related to physico-chemical properties, PAHs and heavy metals. Ecotox. Environ. Safe. 69: 496-505.

Ozores-Hampton, M., Vavrina, C.S., Obreza, T.A. 1999. Yard trimming-biosolids compost: possible alternative to sphagnum peat moss in tomato transplant production. Compost Sci. Uti. 7: 42-49.

Prudent, P., Domeizel, M., Massiani, C. and Thomas, O. 1995. Gel chromatography separation and U.V. spectroscopic characterization of humic-like substances in urban composts. Sci. Total Environ. 172: 229-235.

Raviv, M., Zaidman, B.C., Kapulnik, Y.1998. The use of compost as a peat substitute for organic vegetable transplants production. Compost Sci. Uti. 6: 46-52..

Savarino, P., Montoneri, E., Bottigliengo, S., Boffa, V., Guizzetti, T., Perrone, D.G. and Mendichi, R. 2009. Biosurfactants from urban wastes as auxiliaries for textile dyeing. Ind. Eng. Chem. Res., 48: 3738-3748.

Savarino, P., Montoneri, E., Musso, G. and Boffa, V. 2010. Biosurfactants from urban wastes for detergent formulation: Surface activity and washing performance . J. Surfactants Deterg., 13: 59-68.

Sortino, O., Di Pasquale, M., Montoneri, E., Perrone, D.G., Tomasso, L., Vindrola, D., and Negre, M. 2011. Sustainable Chemistry and Agriculture: Bioorganic Substances Isolated from Municipal Refuse for Tomato Greenhouse Cultivation. Submitted to J. Agric. Food Chem.

Tambone, F., Scaglia, B., D’Imporzano, G., Schievano, A., Orzi, V., Salati, S. and Adani, F. 2010. Assessing amendment and fertilizing properties of digestates from anaerobic digestion through a comparative study with digested sludge and compost. Chemosphere, 81: 575-583.

UNI 10780. 1998. Compost, Classification, requirements and use criteria, December 1998. 
TABLE 1.

Main characteristics of the starting materials

\begin{tabular}{lccccccc}
\hline & $\mathrm{pH}$ & $\begin{array}{c}\mathrm{TOC} \\
(\%)\end{array}$ & $\begin{array}{c}\mathrm{N} \\
(\%)\end{array}$ & $\mathrm{C} / \mathrm{N}$ & $\begin{array}{c}\text { Salinity } \\
(\mathrm{meq} / 100 \mathrm{~g})\end{array}$ & $\mathrm{P}_{2} \mathrm{O}_{5}(\%)$ & $\mathrm{K}(\%)$ \\
\hline GC & 7.3 & $22.4 \pm 0.4$ & $1.91 \pm 0.03$ & 11.7 & 98.4 & $0.39 \pm 0.02$ & $1.18 \pm 0.07$ \\
CGD & 8.2 & $27.1 \pm 0.8$ & $2.45 \pm 0.07$ & 11.1 & 124.9 & $0.75 \pm 0.05$ & $1.09 \pm 0.03$ \\
CGS & 6.6 & $22.9 \pm 0.3$ & $2.36 \pm 0.06$ & 9.7 & 87.0 & $0.92 \pm 0.07$ & $1,02 \pm 0,04$ \\
CGSD & 7.7 & $24.4 \pm 0.2$ & $2.25 \pm 0.11$ & 10.8 & 23.1 & $1.30 \pm 0.22$ & $1.32 \pm 0.03$ \\
SSOD & 8.2 & $30.0 \pm 0.2$ & $3.81 \pm 0.12$ & 7.9 & 518.6 & $3.27 \pm 0.15$ & $0.53 \pm 0.03$ \\
\hline
\end{tabular}

Mean of 3 replicates \pm SD.

TABLE 2.

Main characteristics of the soluble fractions (SBO)

\begin{tabular}{lccccccc}
\hline & $\mathrm{pH}$ & $\begin{array}{c}\text { TOC } \\
(\%)\end{array}$ & $\begin{array}{c}\mathrm{N} \\
(\%)\end{array}$ & $\mathrm{C} / \mathrm{N}$ & $\begin{array}{c}\text { Salinity } \\
(\mathrm{meq} / 100 \mathrm{~g})\end{array}$ & $\begin{array}{c}\mathrm{P}_{2} \mathrm{O}_{5} \\
(\%)\end{array}$ & $\begin{array}{c}\mathrm{K} \\
(\%)\end{array}$ \\
\hline GC SBO & 8.2 & $38.3 \pm 0.1$ & $4.01 \pm 0.03$ & 9.5 & 288.7 & $0.53 \pm 0.05$ & $3.59 \pm 0.21$ \\
CGD SBO & 8.8 & $37.5 \pm 0.0$ & $4.89 \pm 0.03$ & 7.7 & 278.2 & $0.84 \pm 0.04$ & $3.76 \pm 0.07$ \\
CGS SBO & 8.7 & $37.3 \pm 0.4$ & $4.80 \pm 0.07$ & 7.8 & 284.9 & $0.85 \pm 0.00$ & $3.54 \pm 0.02$ \\
CGSD SBO & 8.2 & $35.5 \pm 0,1$ & $4.34 \pm 0.17$ & 8.2 & 154.1 & $1.44 \pm 0.03$ & $5.49 \pm 0.04$ \\
SSOD SBO & 6.4 & $45.1 \pm 0.1$ & $7.87 \pm 0.12$ & 5.7 & 446.8 & $1.14 \pm 0.10$ & $9.15 \pm 0.06$ \\
\hline
\end{tabular}

Mean of 3 replicates \pm SD.

TABLE 3.

Main characteristics of the insoluble fractions (IOR)

\begin{tabular}{lccccccc}
\hline & $\mathrm{pH}$ & $\begin{array}{c}\text { TOC } \\
(\%)\end{array}$ & $\begin{array}{c}\mathrm{N} \\
(\%)\end{array}$ & $\mathrm{C} / \mathrm{N}$ & $\begin{array}{c}\text { Salinity, } \\
(\mathrm{meq} / 100 \mathrm{~g})\end{array}$ & $\begin{array}{c}\mathrm{P}_{2} \mathrm{O}_{5} \\
(\%)\end{array}$ & $\mathrm{K}(\%)$ \\
\hline GC IOR & 8.7 & $18.4 \pm 0.7$ & $1.15 \pm 0.09$ & 16.0 & 160.4 & $0.37 \pm 0.02$ & $1.49 \pm 0.02$ \\
CGD IOR & 8.9 & $22.1 \pm 0.2$ & $1.64 \pm 0.01$ & 13.5 & 529.4 & $1.14 \pm 0.18$ & $2.13 \pm 0.06$ \\
CGS IOR & 9.3 & $23.0 \pm 0.8$ & $1.57 \pm 0,06$ & 14.6 & 324.5 & $1.05 \pm 0.04$ & $2.41 \pm 0.06$ \\
CGSD IOR & 8.3 & $11.7 \pm 0.2$ & $1.02 \pm 0,05$ & 11.5 & 24.2 & $0.53 \pm 0.05$ & $1.32 \pm 0.02$ \\
SSOD IOR & 7.7 & $27.7 \pm 0.1$ & $1.80 \pm 0,05$ & 15.4 & 678.4 & $2.75 \pm 0.03$ & $3.44 \pm 0.05$ \\
\hline
\end{tabular}

Mean of 3 replicates \pm SD. 
TABLE 4.

Germination index $(\% \pm \mathrm{SD})$ of the starting materials.

\begin{tabular}{lccc}
\hline & L. sativum & S. alba & R. sativus \\
\hline GC & $16.0 \mathrm{a} \pm 15.87$ & $6.9 \mathrm{~b} \pm 2.31$ & $3.7 \mathrm{~b} \pm 4.88$ \\
CGD & $9.4 \mathrm{a} \pm 11.83$ & $42.9 \mathrm{a} \pm 14.00$ & $37.5 \mathrm{a} \pm 25.92$ \\
CGS & $23.9 \mathrm{a} \pm 17.62$ & $2.3 \mathrm{~b} \pm 1.66$ & $1.2 \mathrm{~b} \pm 1.41$ \\
CGSD & $0.6 \mathrm{a} \pm 0.19$ & $1.3 \mathrm{~b} \pm 0.35$ & $0.6 \mathrm{~b} \pm 0.09$ \\
SSOD & $0 \mathrm{a} \pm 0.00$ & $0 \mathrm{~b} \pm 0.00$ & $0.1 \mathrm{~b} \pm 0.03$ \\
\hline
\end{tabular}

Within columns, values followed by the same letter are not significantly different, $\mathrm{P}<0.05$.

TABLE 5.

Germination index $(\% \pm \mathrm{SD}))$ of the soluble fractions $(\mathrm{SBO})$.

\begin{tabular}{lccc}
\hline & L. sativum & S. alba & R. sativus \\
\hline GC SBO & 0b \pm 0 & $9.1 \mathrm{~b} \pm 3.87$ & $7.9 \mathrm{~b} \pm 10.12$ \\
CGD SBO & $33.8 \mathrm{ab} \pm 21.30$ & $83.0 \mathrm{a} \pm 37.34$ & $79.0 \mathrm{a} \pm 36.23$ \\
CGS SBO & $63.8 \mathrm{a} \pm 37.73$ & $15.4 \mathrm{~b} \pm 1.33$ & $2.8 \mathrm{~b} \pm 2.44$ \\
CGSD SBO & $0.25 \mathrm{~b} \pm 0.11$ & $0 \mathrm{~b} \pm 0.00$ & $0.5 \mathrm{~b} \pm 0.17$ \\
SSOD SBO & $0 \mathrm{~b} \pm 0.01$ & $0 \mathrm{~b} \pm 0.00$ & $0.2 \mathrm{~b} \pm 0.12$
\end{tabular}

Within columns, values followed by the same letter are not significantly different, $\mathrm{P}<0.05$.

TABLE 6.

Germination index $(\% \pm \mathrm{SD})$ of the insoluble fractions (IOR).

\begin{tabular}{lccc}
\hline & L. sativum & S. alba & R. sativus \\
\hline GC IOR & $6.8 \mathrm{a} \pm 3.60$ & $2.5 \mathrm{c} \pm 3.44$ & $4.3 \mathrm{ab} \pm 7.46$ \\
CGD IOR & $3.1 \mathrm{a} \pm 5.32$ & $24.1 \mathrm{a} \pm 5.54$ & $15.6 \mathrm{a} \pm 7.09$ \\
CGS IOR & $6.5 \mathrm{a} \pm 8.71$ & $13.5 \mathrm{~b} \pm 8.81$ & $4.9 \mathrm{a} \pm 8.52$ \\
CGSD IOR & $0 \mathrm{a} \pm 0.00$ & $0 \mathrm{c} \pm 0.00$ & $0 \mathrm{~b} \pm 0.00$ \\
SSOD IOR & $0 \mathrm{a} \pm 0.00$ & $0 \mathrm{c} \pm 0.00$ & $0 \mathrm{~b} \pm 0.00$
\end{tabular}

Within columns, values followed by the same letter are not significantly different, $\mathrm{P}<0.05$. 
TABLE 7.

Characteristics of $T$. patula plants grown on the substrate mixed with different wastes originated materials.

\begin{tabular}{lcccccc}
\hline & control & CGSD & SSOD & $\begin{array}{c}\text { CGSD } \\
\text { IOR }\end{array}$ & $\begin{array}{c}\text { SSOD } \\
\text { SBO }\end{array}$ & $\begin{array}{c}\text { SSOD } \\
\text { IOR }\end{array}$ \\
& & & & & & \\
\hline Diameter $(\mathrm{cm})$ & $23.7 \mathrm{a} \pm 1.30$ & $23.2 \mathrm{a} \pm 1.64$ & $23.7 \mathrm{a} \pm 2.82$ & $20.6 \mathrm{a} \pm 2.28$ & $21.9 \mathrm{a} \pm 2.33$ & nd \\
Flower number & $18.8 \mathrm{ab} \pm 3.90$ & $20.0 \mathrm{ab} \pm 2.74$ & $21.2 \mathrm{a} \pm 5.89$ & $12.8 \mathrm{~b} \pm 3.70$ & $19.2 \mathrm{ab} \pm 4.15$ & nd \\
Height $(\mathrm{cm})$ & $22.0 \mathrm{a} \pm 2.00$ & $20.4 \mathrm{a} \pm 1.14$ & $21.2 \mathrm{a} \pm 2.39$ & $15.2 \mathrm{~b} \pm 1.92$ & $19.6 \mathrm{a} \pm 1.95$ & nd \\
Dry weight $(\mathrm{g})$ & $10.8 \mathrm{a} \pm 1.14$ & $11.3 \mathrm{a} \pm 0.96$ & $11.9 \mathrm{a} \pm 2.98$ & $8.7 \mathrm{a} \pm 0.87$ & $9.2 \mathrm{a} \pm 2.23$ & nd
\end{tabular}

nd = growth inhibition; within rows, values followed by the same letter are not significantly different, $\mathrm{P}$ $<0.05$.

TABLE 8.

Size and weight of $R$. sativus root. Outdoor experiment.

control

SSOD

CGSD

SSOD SBO

SSOD IOR

CGSD IOR

\begin{tabular}{lcccccc}
\hline Diameter $(\mathrm{cm})$ & $3.5 \mathrm{ab} \pm 0.59$ & $4.1 \mathrm{~b} \pm 0.58$ & $3.4 \mathrm{ab} \pm 0.44$ & $2.9 \mathrm{a} \pm 0.86$ & $\mathrm{nd}$ & $3.2 \mathrm{ab} \pm 1.25$ \\
Dry weight $(\mathrm{g})$ & $0.8 \mathrm{a} \pm 0.36$ & $0.7 \mathrm{a} \pm 0.10$ & $0.6 \mathrm{ab} \pm 0.22$ & $0.3 \mathrm{~b} \pm 0.25$ & $\mathrm{nd}$ & $0.78 \mathrm{a} \pm 0.16$ \\
\hline
\end{tabular}

$\mathrm{nd}=$ growth inhibition; within rows, values followed by the same letter are not significantly different, $\mathrm{P}<$ 0.05 . 
TABLE 9.

Size and weight of R.sativus root. Greenhouse experiment.

\begin{tabular}{|c|c|c|c|c|c|c|c|c|c|c|}
\hline & control & CGS & CGD & $\mathrm{CG}$ & CGS SBO & $\begin{array}{l}\text { CGD } \\
\text { SBO }\end{array}$ & $\begin{array}{c}\mathrm{CG} \\
\mathrm{SBO}\end{array}$ & $\begin{array}{l}\text { CGS } \\
\text { IOR }\end{array}$ & $\begin{array}{l}\text { CGD } \\
\text { IOR }\end{array}$ & $\begin{array}{c}\mathrm{CG} \\
\mathrm{IOR}\end{array}$ \\
\hline $\begin{array}{l}\text { Diameter } \\
(\mathrm{cm})\end{array}$ & $\begin{array}{c}2.6 \mathrm{ad} \pm \\
0.44\end{array}$ & $\begin{array}{l}6.0 \mathrm{bc} \\
\pm 1.03\end{array}$ & $\begin{array}{c}3.8 \text { acd } \pm \\
0.69\end{array}$ & $\begin{array}{c}3.6 \text { acd } \pm \\
0.05\end{array}$ & $\begin{array}{c}4.5 \mathrm{ad} \pm \\
1.06\end{array}$ & $\begin{array}{c}5.1 \text { acd } \pm \\
0.58\end{array}$ & $\begin{array}{c}5.6 \mathrm{ad} \pm \\
0.80\end{array}$ & $\begin{array}{c}4.8 \text { acd } \pm \\
0.73\end{array}$ & $\begin{array}{c}3.0 \mathrm{acd} \pm \\
0.67\end{array}$ & $\begin{array}{c}2.2 \mathrm{a} \pm \\
0.86\end{array}$ \\
\hline $\begin{array}{l}\text { Dry weight } \\
(\mathrm{g})\end{array}$ & $\begin{array}{c}1.7 \mathrm{ac} \pm \\
0.29\end{array}$ & $\begin{array}{c}3.4 \mathrm{bd} \pm \\
0.87\end{array}$ & $\begin{array}{c}3.1 \mathrm{abd} \pm \\
0.65\end{array}$ & $\begin{array}{c}3.4 \mathrm{bd} \pm \\
0.96\end{array}$ & $\begin{array}{c}\text { 3.0abcd } \pm \\
0.25\end{array}$ & $\begin{array}{c}3.6 \mathrm{bd} \pm \\
0.63\end{array}$ & $\begin{array}{c}3.8 \mathrm{~b} \pm \\
1.07\end{array}$ & $\begin{array}{c}2.4 \mathrm{acd} \pm \\
0.54\end{array}$ & $\begin{array}{c}2.0 \mathrm{acd} \pm \\
0.83\end{array}$ & $\begin{array}{c}1.3 \mathrm{c} \pm \\
0.42\end{array}$ \\
\hline
\end{tabular}

Within rows, values followed by the same letter are not significantly different, $\mathrm{P}<0.05$.

TABLE 10.

Dry weight of the leaves of S.oleracea.

\begin{tabular}{cccccccccc}
\hline & control & CGS & CGD & CG & CGS SBO & CGD SBO & CG SBO & CGS IOR & CGD \\
\hline Dry weight $(\mathrm{g})$ & $0.9 \mathrm{a} \pm 0.19$ & $2.9 \mathrm{~b} \pm 0.76$ & $2.9 \mathrm{~b} \pm 1.02$ & $1.3 \mathrm{ab} \pm 0.74$ & $1.6 \mathrm{ab} \pm 0.58$ & $1.9 \mathrm{ab} \pm 0.65$ & $2.4 \mathrm{ab} \pm 1.26$ & $2.3 \mathrm{ab} \pm 0.61$ & $2.4 \mathrm{ab} \pm$
\end{tabular}

Within rows, values followed by the same letter are not significantly different, $\mathrm{P}<0.05$. 